\title{
Negative Side Effects of Lean Management
}

\author{
Andreas Mueller and Stanisław Strzelczak \\ Warsaw University of Technology, Faculty of Production Engineering, Warsaw, Poland \\ a_mueller_84@yahoo.de, s.strzelczak@wip.pw.edu.pl
}

\begin{abstract}
This paper investigates the problem of unplanned negative effects, which may result from implementation of lean management. Using as the basis empirical evidence from European machine tools industry it is argued, that in majority of cases targeted effects (mostly cost savings, production and utilization increase) are followed, with a delay, by negative side effects (mostly unplanned increased costs, quality issues, customer dissatisfaction). It is suggested, that using the controlling framework as management tool may enable to avoid these unlikely effects. Its relevant adoption, to support multi-perspective assessment of lean management implementations is presented within the paper.
\end{abstract}

Keywords: Lean Management, Effects, Multi-perspective Assessment.

\section{Introduction}

In 2007 the Industry Week published an article about a widespread survey performed in USA, which has shown that only $2 \%$ of companies applying Lean Management initiatives meet their planed results [1]. In addition Liker [2] stated that a majority of organizations, which went through improvement programs argue, that after positive effects, a fall back turns in to reverse initial efforts. Recently, the Shingo Award Committee confirmed the last thesis, after investigating on sustainability of business excellence performance of past award winners [3]. The above mentioned fallbacks seem to appear frequently, despite application of modern Lean Management leadership approaches supported by organizational culture changes and intensive trainings. However, the scientific literature usually ignores the problem or walks along its surface, as it mainly lacks empirical background for its deeper analysis.

The purpose of this paper is to reflect on findings from literature and own research, with the intention to analyze roots and reasons, as well as possible ways to tame the above problem. This paper presents different research findings. Eight cases (including expert panels) from four different OEM machinery manufacturing companies are a basis for empirical data, illustrating negative side effects resulting from wrongly controlled or implemented Lean Management initiatives. Apart from that, the literature review regarding the effects of Lean Management and potential ways of their assessment, are presented in the paper, with the intention to avoid the unlikely effects. The conclusions from the research are used as inputs for development of a framework for holistic multi-perspective assessment of Lean Management implementations, by an adoption of the idea of universal controlling [19]. 


\section{Existing Knowledge}

One of the first difficulties met by anybody researching the Lean Management is its fuzzy definition, allowing various interpretations and implementations to be put under the same name. By researching on the term Lean Management a various range of definitions can be identified. Furthermore it seems difficult to identify a definition, which is not affected by lean consultancy. The shortest and easiest definition identified with a scientific background is as follows: Lean management implementation leads to generation of more value for customers with fewer resources as input [4]. Inputs could be described as materials, human resources and financial inputs.

Following the above definition, promising improvements are outlined in the literature, which seem to be dominated by authors directly involved in Lean Management Consultancy. It is often suggested, that with Lean Management it is possible to achieve significant effects, e.g.: lead time reduction of $60-90 \%$, decrease of inventories by $10-50 \%$, shop floor utilization increase by $5-40 \%$ or productivity improvement by $5-25 \%$, just naming few benefits reported e.g. in [5]. This kind of promises makes decision-making and budget allocation for majority of Lean projects easy. However, it is not always sure, if at all, if the mentioned effects will bring only wealth in a long term perspective, as it is presumed in all cases. As was suggested by the quotations in the former section, there are also second momentum effects of Lean management implementation $[1,2,3]$. Other examples of firms suffering from distortions and turbulences after becoming lean corporations are described in some papers [6].

The question arises, when reading publications reporting Lean Management effects is how these were controlled (ex ante and ex post). Surprisingly all quoted publications bypass the methodological of how to control these effects. In general there are various accounting and controlling possibilities to support implementation and observation of Lean Management initiatives. Kaplan and Cooper outline that conservative controlling systems are insufficient for feedback and learning due to delays in reporting, straight attention on financial measures, top-down implementation, focus on localized improvements, individual control and adherence to traditional standards, which cannot support lean [7]. Maskell argues [8], that most of relevant accounting essentials, which modern managers work with, date back to 1930s. He suggests practical lean accounting as a relevant basis for improvements, however with no exact recommendations. Grasso reviewed accounting and controlling possibilities for Lean Management implementation assessment, including the following approaches [16]:

- Kaplan \& Norton: Balanced scorecard [9]

- Staubus: Input/Output costing or Activity Based Costing (ABC) [10]

- Sharman: Flexible margin costing (ger.: Grenzplankostenrechnung - GPK) [11, 12]

- Merwe \& Keys: Resource Consumption Accounting (RCA) [13]

- Dixon, Nanni \& Vollmann: Stage II systems [14]

- Horvath: Process costing (PC) [15]

- Horvath: Integration of PC and GPK in RCA [16]

- Goldratt: Throughput accounting [17]

- Maskell: Lean accounting [18] 
Some of the listed publications directly suggest, that companies should think of a lean controlling system with a practical and simple lean accounting approach $[8,16]$. Universal controlling, as a management tool, is being described by three dimensions: function (strategic or operational), scope (financial, operations and financial or complex) and category (production, logistics etc.). It may incorporate controlling of results and controlling of structures. Aside from controlling dimensions two approaches are used to control different outputs: quantitative outputs and qualitative outputs. The quantitative controlling focuses on mathematic models or applications and reflects to measurement theory and support to the decision-making process. Especially in the past, a pure financial controlling in terms of controlling results and structures had broad attention. Qualitative controlling focuses more on individual attitudes, behavior, group processes, considers industrial psychology, while motivation is a driving force. It is widely applied for qualitative differentiation (characterization) of an organization and enables monitoring or evaluation in a form of non-financial logic.

It is also visible from the reviewed literature, that a multi-perspective method of lean Management assessment is not available, despite several controlling approaches existing in the literature. Quantitative controlling seems improper to create value due to straight attention to monetary benefits, while qualitative controlling might be interesting due to its universalism. The field of multi-perspective assessment of Lean Management is not yet enforced by available literature. The research described below targets to eliminate theses shortcomings, by looking at case study findings and analyzing its results.

\section{$3 \quad$ Research Methodology and Findings}

Considering the main objective of the research, i.e. finding the means to avoid side negative effects of lean management implementation, potentially by a better way of assessment of the effects, two major directions seem to be crucial: to understand the reasons of why negative effects appear and to investigate the tools which may help to recognize the negative effects, if possible in advance, and to measure them.

Apart of the review of existing knowledge, which can be based on the literature sources, there is also evident need to directly recognize the phenomena through empirical research. Unfortunately, due to limited access to the company data (particularly to the quantitative data), the scope of possible approaches for such research is very limited. It has been decided, to avoid any bias, to develop case studies of different implementations of Lean Management, starting from data collection during semistructured interviews, than eventually followed by successive expert panels. These could be also helpful to verify conclusions drawn from the empirical data, which refer to the eventual assessment framework or method. The synthesis of such conclusions was presumed as fundamental for formulation of the holistic multi-perspective method for Lean Management effects assessment, following the integrated global analysis approach. The framework is rooted in the ideas of universal controlling, according to the literature recommendations. The plan of research is presented in a structured way in the below table. 
Table 1. Structure of Research

\begin{tabular}{|l|l|l|}
\hline \multicolumn{1}{|c|}{ Phase } & \multicolumn{1}{|c|}{ Scope } & \multicolumn{1}{c|}{ Methods / Tools } \\
\hline Initial & $\begin{array}{l}\text { Problem conceptualization } \\
\text { Evidence of possible effects } \\
\text { Assessment approaches }\end{array}$ & Analysis of literature \\
\hline Empirical & $\begin{array}{l}\text { Planning interviews } \\
\text { Interviewing }\end{array}$ & $\begin{array}{l}\text { Semi-structured interviewing } \\
\text { Expert panels (2 }\end{array}$ \\
\hline $\begin{array}{l}\text { Analysis } \text { iteration }) \\
\text { results }\end{array}$ & $\begin{array}{l}\text { Results assessment } \\
\text { Summary of findings }\end{array}$ & $\begin{array}{l}\text { Conceptual analysis } \\
\text { Simple statistical analysis }\end{array}$ \\
\hline $\begin{array}{l}\text { Synthesis of } \\
\text { results }\end{array}$ & $\begin{array}{l}\text { Proposal of multi-perspective as- } \\
\text { sessment method }\end{array}$ & Theoretical synthesis \\
\hline
\end{tabular}

Targeting the interviews, four globally operating OEM machinery manufacturers have been approached, to receive first-hand information on specific lean initiatives. All companies have an in house production and engineering. The interviews have been done in different departments in EU. After onsite face to face introduction eight interviews were arranged with middle and senior managers from different work areas (Table 2). Afterwards findings have been later discussed, during the expert panels, to receive detailed information and protect against any bias. Due to confidentiality companies are unnamed. As key performance indicators were not allowed to be published, synthetic quantification of effects or costs is used in the paper.

All eight interviews have been conducted, aiming to discover targeted effects, which managers committed on, prior to lean project starts. In addition, discovery of negative side effects was indirectly targeted. All identified types of targeted effects and side negative effects are listed in table 3.

Table 2. Performed Interviews

\begin{tabular}{c|c|c|l|l|}
\hline Company & Location & Workforce & \multicolumn{1}{|c|}{ Lean Topic } & \multicolumn{1}{|c|}{ Interviewees } \\
\hline A & South Germany & $1000+$ & $\begin{array}{l}\text { Product } \\
\text { Development }\end{array}$ & $\begin{array}{l}\text { Chief technical officer } \\
\text { Head of product development }\end{array}$ \\
\hline B & North Germany & $600+$ & Procurement LCC & $\begin{array}{l}\text { Head of procurement } \\
\text { Senior category manage }\end{array}$ \\
\hline A & South Germany & $1000+$ & Assembly Tact & $\begin{array}{l}\text { Head of assembly } \\
\text { Head of outgoing goods }\end{array}$ \\
\hline C & Switzerland & $500+$ & Assembly LCC & $\begin{array}{l}\text { Head of assembly } \\
\text { Diverse sales managers }\end{array}$ \\
\hline C & Switzerland & $500+$ & $\begin{array}{l}\text { Engineering } \\
\text { Relocation }\end{array}$ & $\begin{array}{l}\text { Head of engineering } \\
\text { Head of business excellence IT }\end{array}$ \\
\hline A & South Germany & $1000+$ & Production LCC & $\begin{array}{l}\text { Head of assembly } \\
\text { Head of human resources }\end{array}$ \\
\hline D & West Germany & $1000+$ & $\begin{array}{l}\text { Machine } \\
\text { Investment }\end{array}$ & $\begin{array}{l}\text { Head of production } \\
\text { Head of quality management }\end{array}$ \\
\hline B & North Germany & $600+$ & $\begin{array}{l}\text { Sales } \\
\text { KPIs }\end{array}$ & $\begin{array}{l}\text { Head of sales } \\
\text { Line manager assembly }\end{array}$ \\
\hline
\end{tabular}


Table 3. Overview of Targeted and Side Effects

\begin{tabular}{|c|l|l|l|}
\hline Interview & \multicolumn{1}{|c|}{ Field and Topic } & \multicolumn{1}{|c|}{ Targeted Effects } & \multicolumn{1}{|c|}{ Negative Effects } \\
\hline 1 & Product Development & $\begin{array}{l}\text { Low development cost } \\
\text { Transparent spending }\end{array}$ & $\begin{array}{l}\text { Additional costs } \\
\text { Quality issues } \\
\text { Customer dissatisfaction }\end{array}$ \\
\hline 2 & Procurement LCC & $\begin{array}{l}\text { Saving supply cost } \\
\text { LCC quote }\end{array}$ & $\begin{array}{l}\text { Additional costs } \\
\text { Penalties, Fall outs } \\
\text { Quality issues }\end{array}$ \\
\hline 3 & Assembly Tact & $\begin{array}{l}\text { Cost savings } \\
\text { Double output } \\
\text { Productivity increase }\end{array}$ & $\begin{array}{l}\text { Additional costs } \\
\text { Increased stock }\end{array}$ \\
\hline 5 & Assembly LCC & $\begin{array}{l}\text { Saving personnel costs } \\
\text { Saving production costs } \\
\text { Low cost suppliers }\end{array}$ & $\begin{array}{l}\text { Additional costs } \\
\text { Customer dissatisfaction } \\
\text { Reduced sales volume } \\
\text { Non-acceptance by own staff }\end{array}$ \\
\hline 8 & Sales KPIs & $\begin{array}{l}\text { Saving production costs } \\
\text { Utilization of plants } \\
\text { Standardization }\end{array}$ & $\begin{array}{l}\text { Additional costs } \\
\text { Quality issues } \\
\text { Missing responsibility }\end{array}$ \\
\hline 7 & Pelocation & $\begin{array}{l}\text { Saving production costs } \\
\text { Low investment cost } \\
\text { Growth in market }\end{array}$ & $\begin{array}{l}\text { Additional costs } \\
\text { Quality issues } \\
\text { Non-acceptance by own staff }\end{array}$ \\
\hline Production LCC & $\begin{array}{l}\text { Saving production cost } \\
\text { Technological advantage } \\
\text { Utilization }\end{array}$ & $\begin{array}{l}\text { Rdditional costs } \\
\text { Bachine Investmenation }\end{array}$ & $\begin{array}{l}\text { Additional costs } \\
\text { Quality issues } \\
\text { Customer dissatisfaction }\end{array}$ \\
\hline
\end{tabular}

It has appeared that for all cases, which were subject of interviewing, implementation plans existed. All of them were including a list of expected gains. Such list in all cases summarized mainly the expected financial benefits and the one-time cost reductions to be achieved. By categorizing findings it becomes clear, that nearly all lean initiatives primarily targeted cost savings, followed by some kind of growth targets (increased sales, etc.) and utilization targets.

When looking at negative side effects observed, it becomes evident that in all cases the implementations of Lean Management initiatives were later followed by some unexpected additional costs (losses), around or even inside the lean system, and additionally by unplanned quality issues (in every second project), and by some kind of customer dissatisfaction (in about every third project).

An effort to measure all effects was also undertaken during the performed research. As they were of different type and some could not be measured easily in a natural way, all interviewees were asked to allocate a weight ranging from 0 as minimum to 6 as maximum, to the targeted (i.e. positive) and negative (i.e. side) effects. The average assessments for all cases are illustrated at Fig.1. 


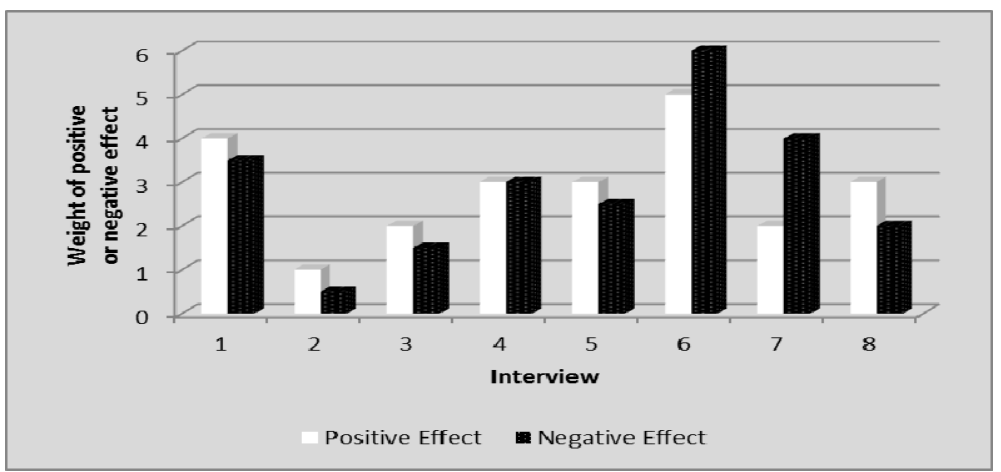

Fig. 1. Absolute Quantification of Lean Management target and side effects (sequence of interviews as in table 3 )

By comparing the initially planned targeted effects with the observed negative side effects, it is clear that in some cases side negative effects are higher than the priory planned effects, reflecting that unplanned costs overtake planned benefits. Furthermore, in even no one case the planned effects exceeded significantly (i.e. by one order) the negative side effects.

The interviewed managers were also asked about their opinions concerning assessment of the effects. A fixed numerical baseline in a form of starting point, to track the progress, was always considered as a basis to follow up targeted savings. This means that a kind of primitive controlling of targeted effects was applied in all cases. A general opinion can be also formulated, that a strong focus on financial controlling seems to be an inappropriate for Lean projects implementation. Many interviewees stressed, that missed link between Lean initiative and overall strategy, together with changing environmental conditions, ignored risks due to profitability pressure, drive negative side effects, making counteracting after first appearance nearly impossible.

The scale of identified negative effects of Lean Management implementations together with the existing methodological shortcomings support the conclusion that the Lean Management implementations should be preceded, then monitored in a more systematic and rigid way. Particularly choosing the Lean Management initiatives and their targeted effects should be rooted in the strategic planning and done with reference to the strategic company goals, then rigidly monitored by the controlling means.

\section{Multi-perspective Assessment of Lean Management}

Following the conclusions from research, an initial framework for multi-perspective assessment of Lean Management implementations has been developed to overcome existing methodological shortcomings, using the idea of universal controlling (Fig.2). The intention behind the proposed model is to maintain a connection between strategic planning, which embeds strategy, objectives, time frame and risk assessment of an entire corporation, with a way of selection of particular processes to be improved by the Lean Management methodology. This way the targeted processes improvement initiatives receive information inputs for further detailed analysis directly from the overall company data, including key performance indicators and their trendlines. 


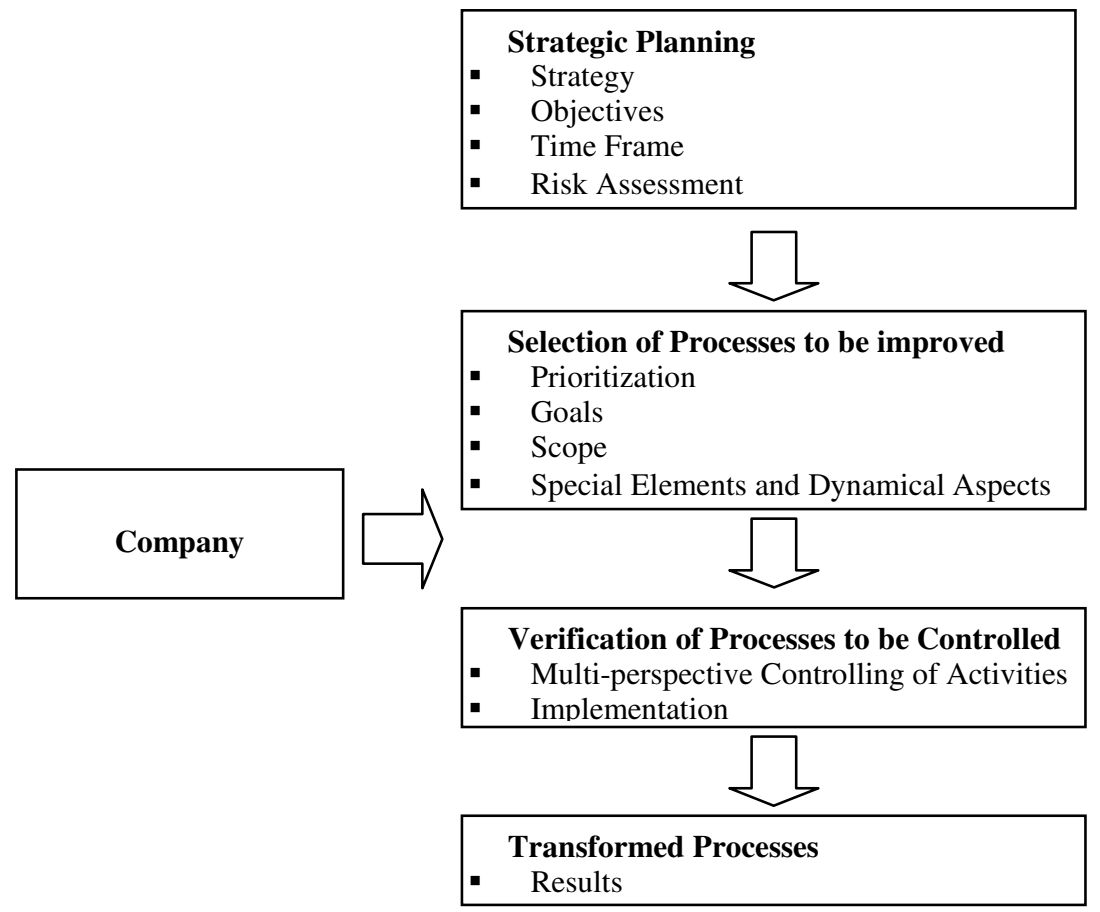

Fig. 2. Framework for a method for multi-perspective assessment of Lean Management

After prioritization and goals setting the scope of implementation may be defined in a justified way. Then some special elements or dynamical aspects may be considered. Within a verification stage a multi-perspective controlling of activities is being applied before an implementation starts. Finally when implementation has taken place, results are being evaluated, monitored and considered as new baseline for next improvements.

\section{Conclusions}

The evidence form performed research suggests, that all the interviewed managers agree about existing practices on Lean Management assessment, as having many shortcomings. Particularly strict financial controlling of arbitrary selected savings should not be used as a stand-alone instrument for Lean project implementation. An initial model for multi-perspective assessment been therefore developed, intending to connect Lean Management with strategic planning and qualitative controlling, to overcome the problem of negative side effects of Lean Management implementations.

Despite the fact that quantitative controlling, or in particular a focused financial controlling of reduced cost items is applied to plan and monitor benefits and costs of projects, it is confirmed that in most cases unplanned turbulences appear to reverse, or at least significantly reduce initially planned target effects. 
Looking at presented examples it is questionable if the common definition of Lean Management, which promotes gain of value for customers from reduced input of resources, is actually respected. It seems more like a restrictive framework for mediumterm projects, aiming reduced costs, while level of innovation and quality is hoped to be steady, but sustainability is not ensured. Quantitative improvements of focused effects seem promising and seductive at the same time, but leaving the question of long-term sustainability of effects, and suggesting the need for multi-perspective assessment of lean initiatives. As the presented proposal is only initial, it should be a subject for further research and verification.

\section{References}

1. IndustryWeek/MPI Census of Manufacturers (November 2007), http://www.industryweek.com/articles/everbodys_jumping_on_the_ lean_bandwagon_but_many_are_being_taken_for_a_ride_15881.aspx

2. Liker, J.K., Franz, J.K.: The Toyota Way to Continuous Improvement, p. 12. McGraw-Hil (2011)

3. Miller, R. (executive director of the Shingo Prize): Interview on radiolean.com (July 2010)

4. Lean Enterprise Institute Inc., Cambridge, http: / / www. lean. org/whatslean/

5. Hobbs, D.P.: Applied Lean Business Transformation: A Complete Project Management Approach. In: Ross Pub, J. (ed.) J. Ross Pub. Inc., p. 5 (2011)

6. Cusumano, M.A.: The Limits of "Lean". Sloan Management Review 1994/VI

7. Kaplan, R., Cooper, R.: Design of Cost Management Systems, Prentice Hall, p. 37 (1998)

8. Stenzel, J., Maskell, B.: Lean Accounting: Best Practices for Sustainable Integration, p. 55. John Wiley \& Sons (2007)

9. Kaplan, R.S., Norton, D.P.: The Balanced Scorecard: Translating Strategy Into Action. Harvard Business School Press (1996)

10. Staubus, G.J.: Activity Costing and Input-Output Accounting, Richard D.Irwin (1971)

11. Sharman, P.: The Case for Management Accounting, Strategic Finance, 2003/X

12. Sharman, P.: German Cost Accounting, StrategicFinance, 2003/X

13. Van der Merwe, A., Keys, D.E.: The Case for Resource Consumption Accounting, Strategic Finance, 2002/IV

14. Dixon, R., Nanni, A., Vollmann, T.: The New Performance Challenge: Measuring Operations for World-Class Competition, Dow Jones-Irwin (1990)

15. Prozeßkostenmanagement: Methodik und Anwendungsfelder, Vahlen, Horvath \& Partner $\mathrm{GmbH}, 1998 / \mathrm{VI}$

16. Grasso, L.P.: Are ABC and RCA Accounting Systems Compatible with Lean Management? Management Accounting Quarterly 7/1 (2005)

17. Goldratt, E.: What Is This Thing Called Theory of Constraints. North River Press (1990)

18. Maskell, B.: Practical Lean Accounting: A Proven System for Measuring and Managing the Lean Enterprise. Productivity Press (2011)

19. Marciniak, S.: Controlling - Theory and Applications, ch. 2\&3. Diffin (2007) (in Polish) 